\title{
PENERAPAN MODEL TUTORIAL BERBANTUAN MATHEMATICA UNTUK MENINGKATKAN KEMAMPUAN PEMECAHAN MASALAH MATEMATIS
}

\author{
Suwarno \\ Universitas BINUS \\ Suwarno10288@gmail.com
}

\begin{abstract}
ABSTRAK
Penelitian ini bertujuan untuk menganalisis perbedaan peningkatan kemampuan pemecahan masalah mahasiswa yang menggunakan pembelajaran model tutorial berbantuan Mathematica dan mahasiswa yang menggunakan pembelajaran tanpa berbantuan Mathematica bila ditinjau secara keseluruhan dan ditinjau dari kategori pengetahuan awal matematika (tinggi, sedang, rendah). Penelitian ini merupakan penelitian kuasi eksperimen. Pelaksanaan penelitian ini dilakukan pada mahasiswa yang mengikuti perkuliahan Kalkulus 1 pada salah satu Perguruan Tinggi Swasta di Tangerang. Perkuliahan Kalkulus 1 terdiri atas 4 kelas dengan jumlah mahasiswa sebanyak 120 orang. Dua kelas dipilih secara Purposive Sampling untuk dijadikan kelas kontrol dan kelas eksperimen. Kedua kelas (60 orang) diberikan pretes dan postes yang berkaitan dengan kemampuan pemecahan masalah. Pada kelas eksperimen diberikan instrument non-tes berupa angket untuk mengetahui respon mahasiswa. Hasil penelitian menunjukkan bahwa mahasiswa yang menggunakan pembelajaran integral berbantuan Mathematica peningkatan kemampuan pemecahan masalah mahasiswa secara signifikan lebih baik dibandingkan dengan mahasiswa yang memperoleh pembelajaran integral tanpa berbantuan Mathematica. Selain itu, penggunaan Mathematica dalam proses pembelajaran dapat menciptakan pembelajaran matematika yang interaktif sehingga mahasiswa memberikan respon positif terhadap pembelajaran matematika.
\end{abstract}

Kata Kunci : Kemampuan pemecahan masalah matematis, model tutorial berbantuan Mathematica, dan pembelajaran konvensional.

\section{PENDAHULUAN}

Pada tahun pertama mahasiswa STKIP Surya memulai perkuliahan, mahasiswa wajib mengikuti suatu program perkuliahan yang diadakan oleh universitas. Program perkuliahan ini dikenal dengan sebutan Program Matrikulasi. Pada program ini, mahasiswa belajar kembali konsep matematika yang telah dipelajari saat belajar di Sekolah Dasar dan Sekolah Menengah. Pada tahun kedua, mata kuliah keahlian yang wajib diikuti oleh mahasiswa yaitu mata kuliah Pra Kalkulus 1 dan Pra Kalkulus 2. Mata kuliah Pra kalkulus 1 membekali mahasiswa dengan pengetahuan tentang dasar-dasar pengetahuan matematika untuk mata kuliah kalkulus. Mata kuliah ini membahas tentang himpunan dan sistim bilangan, persamaan dan pertidaksamaan, fungsi, jenis-jenis fungsi, fungsi logaritma dan 
fungsi eksponensial, fungsi trigonometri, Fungsi invers trigonometri, serta persamaan dan pertidaksamaan trigonometri.

Dasar-dasar pengetahuan matematika yang telah dibekali selama dua tahun masa perkuliahan seharusnya membuat mahasiswa semakin terampil dalam memahami konsepkonsep matematika. Namun, hasil belajar mahasiswa pada mata kuliah Kalkulus 1 pada tahun akademik 2013/2014 ternyata belum memuaskan. Hal ini terlihat dari nilai akhir yang diperoleh mahasiswa pada mata kuliah tersebut. Selain hasil belajar yang belum memuaskan, mahasiswa juga belum menguasai konsep matematika yang telah dipelajari selama dua tahun masa perkuliahan. Hal ini menunjukkan bahwa kualitas hasil pembelajaran mata kuliah Kalkulus 1 belum optimal. Oleh karena itu, diperlukan solusi untuk mengatasi hal tersebut.

Beberapa fakta yang peneliti temukan terkait dengan proses pembelajaran mata kuliah Kalkulus 1 yaitu adanya kecenderungan mahasiswa yang hanya menghafal konsep dan contoh-contoh yang diberikan oleh dosen. Hal ini berakibat terjadinya miskonsepsi yang dapat menghambat pemahaman konsep matematika selanjutnya. Selain itu, mahasiswa kurang memperoleh pengalaman baru yang dapat meningkatkan motivasi dan aktivitas belajarnya.

Miskonsepsi dalam pembelajaran kalkulus ternyata juga terjadi di beberapa Negara. Sebagai contoh, Muzangwa dan Chifamba (2012) melakukan penelitian terhadap mahasiswa matematika di Great Zimbabwe University. Pada penelitian tersebut, Muzangwa dan Chifamba melakukan analisis kesalahan dan miskonsepsi dalam mata kuliah kalkulus pada jenjang pendidikan strata 1.

Metode penelitian yang dilakukan oleh Muzangwa dan Chifamba yaitu mengeksplorasi kesalahan, miskonsepsi dan penyebabnya dalam mata kuliah kalkulus yang ditawarkan kepada mahasiswa matematika. Tes digunakan untuk mengumpulkan data dari peserta didik. Tes yang digunakan mencakup semua topik utama dalam kalkulus yaitu limit, kekontinuan, fungsi dari beberapa variabel, turunan parsial, integral multivariabel dan aplikasinya. Pretes diberikan pada awal perkuliahan untuk menilai tingkat kemampuan peserta didik dan memeriksa apakah miskonsepsi tertentu karena latar belakang peserta didik.

Penelitian serupa juga dilakukan oleh Kiat (2005). Kiat melakukan penelitian terhadap siswa sekolah menengah di Singapura untuk menganalisis kesulitan siswa dalam menyelesaikan permasalahan integral. Pada penelitian tersebut, Kiat merujuk pada 
penelitian yang dilakukan oleh Orton (1983a). Kiat membagi kemungkinan kesalahan yang dilakukan oleh siswa kedalam tiga kategori, yaitu:

1. Kesalahan konseptual, yaitu kesalahan yang terjadi karena siswa tidak memahami konsep-konsep yang terlibat dalam masalah atau kesalahan yang timbul dari ketidakmampuan siswa untuk menentukan hubungan yang terlibat dalam masalah.

2. Kesalahan prosedural, yaitu kesalahan yang terjadi karena ketidakmampuan siswa untuk melakukan manipulasi atau algoritma meskipun telah memahami konsep dibalik masalah.

3. Kesalahan teknis, yaitu kesalahan yang terjadi karena kurangnya pengetahuan konten matematika dalam topik lain atau kesalahan karena kecerobohan.

Ternyata kesalahan-kesalahan seperti yang telah dipaparkan juga peneliti temukan pada mahasiswa program studi pendidikan matematika STKIP Surya yang telah mengikuti perkuliahan matrikulasi, Pra Kalkulus 1, dan Pra Kalkulus 2. Berikut ini kesalahankesalahan mahasiswa yang peneliti temukan dalam menyelesaikan permasalahan integral.

1. Kesalahan konseptual

Kesalahan ini timbul karena mahasiswa tidak mampu memahami beberapa konsep penting untuk mencari luas daerah integral.

Contoh soal:

Tentukan luas daerah yang dibatasi kurva $y=x(x-2)$, sumbu-X, $x=0$ dan $x=5$.

Berikut ini salah satu jawaban mahasiswa.

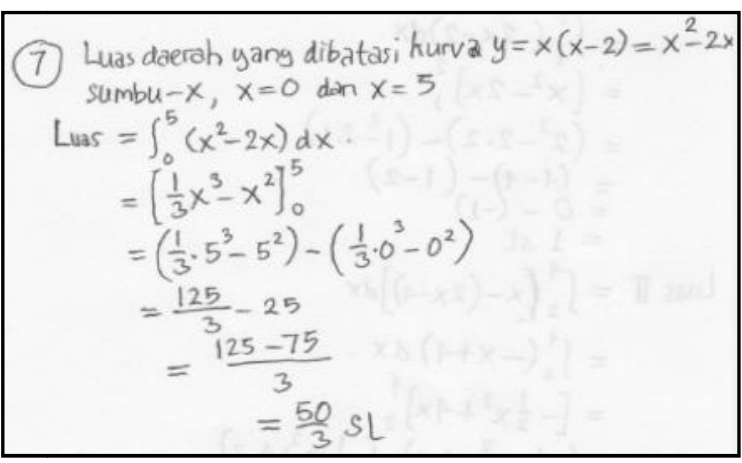

Gambar 1. Kesalahan konseptual dalam mencari luas daerah

Pada kasus tersebut, mahasiswa tidak menyadari bahwa daerah yang dibatasi oleh kurva $y=x(x-2)$, sumbu-X, $x=0$ dan $x=5$ akan terbentuk 2 daerah, yaitu

1) Daerah berada di bawah sumbu-X dari $x=0$ sampai $x=2$

2) Daerah berada di atas sumbu-X dari $x=2$ sampai $x=5$ 
2. Kesalahan prosedural

Kesalahan ini timbul karena mahasiswa tidak mampu melakukan manipulasi aljabar.

Contoh soal:

Jika $\int_{1}^{3} f(x) d x=5$ maka $\int_{1}^{3}(f(x)+3) d x$ adalah ...

Berikut ini salah satu jawaban mahasiswa.

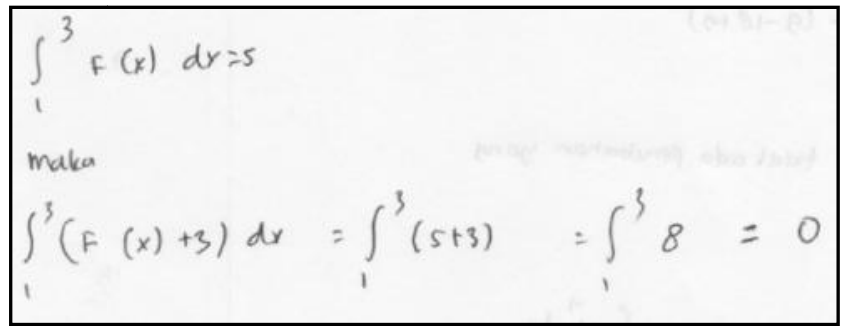

Gambar 2. Kesalahan dalam melakukan manipulasi aljabar

Pada kasus tersebut, mahasiswa langsung mengganti fungsi $f(x)$ dengan nilai 5 .

Seharusnya diuraikan terlebih dahulu menjadi $\int_{1}^{3} f(x) d x+\int_{1}^{3} 3 d x$.

Berdasarkan fakta-fakta di atas, diperlukan suatu alternatif pembelajaran yang lebih inovatif sehingga kesalahan-kesalahan tersebut dapat dihilangkan atau dikurangi. Salah satu alternatif pembelajaran yang dapat digunakan yaitu dengan memanfaatkan Computer Algebra System(CAS) dalam proses pembelajaran. Ruthven, Rousham dan Chaplin (Tolga 2009) memberikan kesimpulan pada akhir penelitiannya, yaitu:

1. CAS memiliki peran positif sebagai alat kognitif.

2. CAS dapat memberikan kesempatan untuk belajar dengan masalah non-rutin.

3. CAS dapat menyediakan lingkungan belajar yang interaktif.

4. CAS memiliki kapasitas dalam memperbesar batasan pikiran.

Barker (2004) menyarankan penggunaan teknologi komputer untuk mendukung pemecahan masalah dan untuk meningkatkan pemahaman. Mahasiswa jurusan matematika harus dapat mengembangkan keterampilan dengan berbagai alat teknologi. Semua jurusan harus memiliki pengalaman dengan berbagai alat teknologi seperti sistem aljabar komputer, software visualisasi, paket statistik, dan bahasa pemrograman komputer.

Selain itu, Barker juga mengatakan bahwa program di semua tingkatan harus: 1) memasukkan kegiatan yang akan membantu siswa belajar untuk menggunakan teknologi sebagai alat untuk memecahkan masalah, dan 2) memanfaatkan teknologi sebagai bantuan 
untuk pemahaman ide-ide matematika. Selain itu, di dalam struktur kurikulum 2013 teknologi informasi dan komunikasi menjadi sarana pembelajaran pada semua mata pelajaran. Hal ini berarti bahwa walaupun teknologi informasi dan komunikasi tidak dicantumkan sebagai mata pelajaran, tetapi keterampilan menggunakan tools teknologi informasi dan komunikasi harus dikuasai untuk menunjang proses pembelajaran.

Mathematica merupakan salah satu perangkat lunak (software) yang termasuk dalam Computer Algebra System (CAS). Penggunaan Mathematica dalam pembelajaran matematika telah dilakukan oleh para peneliti. Salah satunya, penelitian yang dilakukan oleh Kim. Kim (2003) mengatakan bahwa memvisualisasikan konsep-konsep matematika yang abstrak menggunakan Mathematica memungkinkan siswa untuk memahami masalah matematika secara efektif di kelas. Pengembangan jenis-jenis pengajaran dan model pembelajaran dapat merangsang keingintahuan siswa tentang matematika dan meningkatkan minat mereka. Kim juga mengatakan bahwa software matematika dan teknologi lainnya dapat merangsang pendidikan matematika yang lebih baik. Kim menggunakan Mathematica pada materi transformasi linear, trigonometri, dan kalkulus integral yang meliputi jumlahan Riemann dan volum benda putar.

Berdasarkan penjelasan di atas, penulis mengajukan sebuah penelitian terhadap aktivitas pembelajaran matematika, khususnya materi integral dengan menggunakan software Mathematica untuk meningkatkan kemampuan pemecahan masalah matematis.

\section{METODE PENELITIAN}

\section{Desain Penelitian}

Penelitian ini menggunakan metode kuasi-eksperimen. Dalam penelitian ini diambil sampel dua kelas dengan pembelajaran yang berbeda. Kelompok pertama diberikan pembelajaran berbantuan software Mathematica sedangkan kelompok kedua diberikan perlakuan dengan pembelajaran konvensional sebagai kelas kontrol. Desain yang digunakan dalam penelitian ini adalah Pretest-Postest Control Group Design (Desain Kelompok Pretes-Postes). Tes statistik dilakukan dua kali yaitu sebelum proses pembelajaran (pretes) dan setelah proses pembelajaran (postes). Desain penelitian tersebut direpresentasikan sebagai berikut:

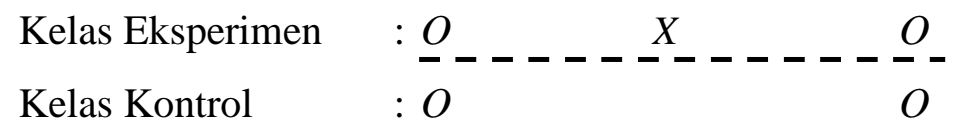

Keterangan: 
$O=$ Tes (Pretest atau Posttest) kemampuan pemecahan masalah

$X=$ Perlakuan (Pembelajaran integral dengan model tutorial berbantuan software Mathematica)

\section{Populasi dan Sampel}

Populasi dalam penelitian ini adalah mahasiswa STKIP Surya yang mengikuti mata kuliah Kalkulus 1 yang terdiri atas 4 kelas dengan jumlah mahasiswa sebanyak 120 orang. Pengambilan sampel dilakukan dengan menggunakan Sampling Purposive, yaitu teknik pengambilan sampel berdasarkan pertimbangan tertentu (Sugiyono 2012). Tujuan dilakukan pengambilan sampel dengan teknik ini adalah agar penelitian yang akan dilakukan dapat dilaksanakan secara efektif dan efisien terutama dalam hal kondisi subyek penelitian dan waktu penelitian. Berdasarkan teknik pengampilan sampel tersebut diambil sampel dua kelas yang terdiri atas 60 orang. Kedua kelas yang terpilih merupakan dua kelompok penelitian yang akan mendapatkan pembelajaran dengan pendekatan yang berbeda. Satu kelas merupakan kelompok eksperimen dan kelas lainnya sebagai kelompok kelas kontrol.

\section{Instrumen Penelitian}

Instrumen yang digunakan pada penelitian ini berupa tes dan non-tes. Intrumen tes terdiri dari tes kemampuan pemecahan masalah dalam bentuk uraian. Sedangkan instrumen non-tes yaitu skala sikap mahasiswa dan lembar observasi.

\section{HASIL DAN PEMBAHASAN}

Berdasarkan pengolahan data diperoleh data statistik hasil tes sebagai berikut.

Tabel 1. Data statistik skor pretes, postes, dan $N$-gain berdasarkan kelas

\begin{tabular}{|c|c|c|c|c|c|c|c|c|}
\hline \multirow{2}{*}{ Statistik } & \multicolumn{4}{|c|}{ Eksperimen } & \multicolumn{4}{|c|}{ Kontrol } \\
\hline & $\mathbf{N}$ & Pretes & Postes & N-Gain & $\mathbf{N}$ & Pretes & Postes & N-Gain \\
\hline $\bar{X}$ & \multirow{2}{*}{30} & 15,50 & 19,93 & 0,05 & \multirow{2}{*}{30} & 11,73 & 12,43 & 0,01 \\
\hline SD & & 8,56 & 7,58 & 0,08 & & 4,43 & 5,90 & 0,07 \\
\hline
\end{tabular}

(Keterangan: skor ideal yaitu 52)

Berdasarkan Tabel 1, rerata postes mahasiswa pada kelas eksperimen lebih tinggi dibandingkan rerata postes mahasiswa kelas kontrol. Selain itu, terlihat bahwa kelas eksperimen maupun kelas kontrol mengalami peningkatan setelah dilakukan kegiatan pembelajaran. Selanjutnya, untuk mengetahui apakah terdapat perbedaan peningkatan 
kemampuan pemecahan masalah mahasiswa pada kelas eksperimen dan kelas kontrol dilakukan uji perbedaan rerata.

Tabel 2. Uji normalitas data peningkatan kemampuan pemecahan masalah

\begin{tabular}{|lcc|}
\hline & \multicolumn{2}{c|}{$N$-gain } \\
\cline { 2 - 3 } & Eksperimen & Kontrol \\
\hline $\mathrm{N}$ & 30 & 30 \\
\hline Kolmogorov-Smirnov $\mathrm{Z}$ & 0,15 & 0,14 \\
\hline Asymp. Sig. (2-tailed) & 0,08 & 0,16 \\
\hline
\end{tabular}

$\mathrm{H}_{0}$ : data peningkatan kemampuan pemecahan masalah berdistribusi normal

$\mathrm{H}_{1}$ : data peningkatan kemampuan pemecahan masalah tidak berdistribusi normal

Berdasarkan Tabel 2, diperoleh nilai Asymp. Sign (2-tailed) $>\alpha=0,05$ untuk kelas eksperimen maupun kelas kontrol, sehingga $\mathrm{H}_{0}$ diterima. Hal ini menunjukkan bahwa kelas eksperimen dan kelas kontrol berdistribusi normal. Selanjutnya, setelah kelas eksperimen dan kelas kontrol diketahui berdistribusi normal maka dilakukan uji homogenitas.

Tabel 3. Uji homogenitas data peningkatan kemampuan pemecahan masalah

\begin{tabular}{|ccccc|}
\hline $\begin{array}{c}\text { Levene } \\
\text { Statistic }\end{array}$ & df1 & df2 & Sig. & Kesimpulan \\
\hline 1,20 & 1 & 58 & 0,28 & Homogen \\
\hline
\end{tabular}

$\mathrm{H}_{0}$ : variansi data peningkatan kemampuan pemecahan masalah homogen

$\mathrm{H}_{1}$ : variansi data peningkatan kemampuan pemecahan masalah tidak homogen

Berdasarkan Tabel 3, disimpulkan bahwa data peningkatan kemampuan pemecahan masalah matematis mahasiswa memiliki nilai Sig. $>\alpha=0,05$, sehingga $\mathrm{H}_{0}$ diterima. Dengan kata lain, data peningkatan kemampuan pemecahan masalah matematis mahasiswa kelas eksperimen dan kelas kontrol berasal dari variansi yang homogen. Setelah data diketahui berdistribusi normal dan memiliki varian yang homogen, selanjutnya dilakukan uji perbedaan rerata menggunakan uji $t$.

Tabel 4. Uji perbedaan dua rerata data peningkatan kemampuan pemecahan masalah

\begin{tabular}{|c|c|c|c|c|c|}
\hline & $\mathrm{t}$ & df & Sig.(2 tail) & Keterangan & Kesimpulan \\
\hline Equal variances assumed & 2,09 & 58 & 0,04 & & \\
\hline $\begin{array}{l}\text { Equal variances not } \\
\text { assumed }\end{array}$ & 2,09 & 55,19 & 0,04 & $\mathrm{H}_{0}$ ditolak & Hipotesis ditolak \\
\hline
\end{tabular}

Pada tabel di atas, diperoleh nilai signifikansi sebesar 0,04. Nilai tersebut lebih kecil dari nilai $\alpha=0,05$ sehingga $\mathrm{H}_{0}$ ditolak. Hal ini menunjukkan bahwa peningkatan 
kemampuan pemecahan masalah mahasiswa yang memperoleh pembelajaran model tutorial berbantuan software Mathematica lebih baik dibandingkan dengan mahasiswa yang memperoleh pembelajaran tanpa berbantuan software Mathematica.

Peningkatan kemampuan pemecahan masalah mahasiswa yang memperoleh pembelajaran model tutorial berbantuan software Mathematica lebih baik dibandingkan dengan mahasiswa yang memperoleh pembelajaran tanpa berbantuan software Mathematica. Mahasiswa menggunakan software Mathematica hanya untuk membantu sebatas perhitungan yang rumit dan membuat animasi volum benda putar. Kemampuan mahasiswa dalam memberikan alternatif jawaban terhadap pemecahan masalah matematis sangat dipengaruhi oleh kreatifitas berpikir mahasiswa itu sendiri dalam menemukan metode lain untuk menyelesaikan masalah.

Berdasarkan analisis skala sikap mahasiswa, dapat disimpulkan bahwa mahasiswa pada kelas eksperimen memberikan respon positif terhadap pembelajaran integral berbantuan software Mathematica. Sikap positif tersebut memberikan dampak yang baik terhadap peningkatan kemampuan pemahaman dan pemecahan masalah mahasiswa. Hasil skala sikap ini sesuai dengan pendapat Hamalik (Pujiadi 2008), bahwa pemakaian media pembelajaran mampu membangkitkan keinginan, minat, motivasi, dan rangsangan kegiatan belajar, bahkan membawa pengaruh psikologis terhadap siswa. Penggunaan media juga akan membantu meningkatkan efektifitas pembelajaran.

Pembelajaran integral berbantuan software Mathematica mudah diterapkan pada mahasiwa. Hal ini karena mahasiswa sudah terbiasa menggunakan komputer dan bisa memahami langkah-langkah yang terdapat pada modul pembelajaran yang diberikan. Modul pembelajaran ini membantu mahasiswa dalam memahami tools dan script pemrograman yang terdapat pada software Mathematica. Namun, mahasiswa masih perlu didampingi oleh dosen agar tujuan pembelajaran yang diharapkan tercapai.

Pembelajaran integral berbantuan software Mathematica memberikan pengalaman yang berkesan bagi mahasiswa. Hal ini karena mahasiswa belum pernah belajar materi integral berbantuan software matematika. Selain itu, penggunaan software Mathematica dalam pembelajaran materi integral membantu mahasiswa untuk belajar secara mandiri. Hal ini karena software Mathematica memberikan langkah-langkah penyelesaian dalam perhitungan integral sehingga mahasiswa dapat mencocokkan hasil pekerjaan yang telah diselesaikan. Menurut Kustandi (2011), komputer dapat mengakomodasi siswa yang lamban menerima pelajaran, merangsang siswa untuk mengerjakan latihan dan melakukan 
kegiatan simulasi. Hal ini karena tersedianya animasi grafik dan warna sehingga dapat menambah realisme.

\section{KESIMPULAN}

Berdasarkan penelitian yang telah dilakukan dapat disimpulkan sebagai berikut:

1. Peningkatan kemampuan pemecahan masalah mahasiswa dengan pembelajaran model tutorial berbantuan software Mathematica lebih baik dibandingkan mahasiswa yang memperoleh pembelajaran tanpa berbantuan software Mathematica.

2. Berdasarkan kemampuan awal mahasiswa, terdapat perbedaan peningkatan kemampuan pemecahan masalah baik pada mahasiswa dengan kemampuan awal rendah, sedang, maupun tinggi pada pembelajaran berbantuan software Mathematica.

3. Mahasiswa memiliki respon positif terhadap pembelajaran berbantuan software Mathematica.

\section{REKOMENDASI}

Berdasarkan hasil penelitian, terdapat beberapa hal rekomendasi yang peneliti ajukan terkait dengan penelitian ini, antara lain:

1. Bahan ajar berbantuan software Mathematica dapat dijadikan salah satu alternatif pembelajaran dalam menjelaskan materi yang memerlukan visualisasi berupa grafik maupun animasi.

2. Sebelum dilakukan pembelajaran, sebaiknya mahasiswa dilatih terlebih dahulu penggunaan software Mathematica yang akan digunakan dalam proses pembelajaran.

3. Penelitian ini hanya terbatas pada materi integral satu variabel. Diharapkan pada penelitian selanjutnya, penelitian lain dapat menggunakan software Mathematica dalam pembelajaran kalkulus yang lain seperti limit dan turunan.

4. Penelitian ini dibatasi pada pengembangan kemampuan pemahaman matematis dan pemecahan masalah mahasiswa tingkat universitas. Pada penelitian selanjutnya tidak menutup kemungkinan dilakukan untuk mengembangkan kemampuan matematis yang lain.

5. Modul pembelajaran sangat membantu mahasiswa dalam mengikuti pelajaran. Tetapi, peran serta dosen sangat diperlukan dalam mengarahkan mahasiswa untuk mencapai tujuan pembelajaran. 
Bagi peneliti lain, software Mathematica dapat digunakan dalam pengembangan bahan ajar berbasis website. Hal ini karena kemampuan software Mathematica yang dapat diintegrasikan pada script html.

\section{UCAPAN TERIMA KASIH}

Penulis menyadari sepenuhnya selama penyusunan penelitian ini, penulis banyak mendapat bantuan, bimbingan, arahan, serta motivasi dari berbagai pihak. Penulis ingin menyampaikan ucapan terima kasih kepada Bapak Turmudi, M.Ed., M.Sc., Ph.D. selaku pembimbing sekaligus sebagai Ketua Program Studi Pendidikan Matematika Universitas Pendidikan Indonesia yang telah meluangkan waktu untuk berdiskusi memberikan bimbingan, arahan, dan motivasi kepada penulis sehingga dapat menyelesaikan penelitian ini.

\section{REFERENSI}

Barker, W. et, al. (2004). Undergraduate Program and Courses in The Mathematical Sciences:CUPM Curriculum Guide 2004. United States Of America: The Mathematical Association of America.

Kabaca, Tolga, Yilmaz A., \& Muharrem A. (2009). The Use of Computer Algebra Systems in Calculus Teaching: Principles and Sample Applications. Croatia: InTech.

Kiat, S. E. (2005). Analysis of Students' Difficulties in Solving Integration Problem. The Mathematics Educator. 9, (1), 39-59.

Kim, H. S. (2003). Teaching and Learning Models for Mathematics using Mathematica (I). Journal of the Korea Society of Mathematical Education Series. 7, (2), 101-123.

Kustandi, C. dan Bambang S. (2011). Media Pembelajaran Manual dan Digital. Bogor: Ghalia Indonesia.

Muzangwa, Jonatan \& Peter C. (2012). Analysis of Errors and Misconception in The Learning of Calculus By Undergraduate Students. Acta Didactica Napocentia. 5, (2), ISSN 2065-1430.

Orton, A. (1983a). Student Understanding of Integration. Educational Studies in Mathematics. 14, (1), 1-18.

Pujiadi. (2008). Pengaruh Model Pembelajaran Matematika Creative Problem Solving (CPS) Berbantuan CD Interaktif Terhadap Kemampuan Pemecahan Masalah Pada Siswa SMA Kelas X. Tesis PPS UNNES: tidak diterbitkan. 
Sugiyono. (2012). Metode Penelitian Pendidikan. Cetakan Ke-14. Bandung: Alfabeta. 
